Article

\title{
Effect of $\mathrm{Gd}_{0.2} \mathrm{Ce}_{0.8} \mathrm{O}_{1.9}$ nanoparticles on the oxygen evolution reaction of $\mathrm{La}_{0.6} \mathrm{Sr}_{0.4} \mathrm{Co}_{0.2} \mathrm{Fe}_{0.8} \mathrm{O}_{3-\delta}$ anode in solid oxide electrolysis cell
}

\author{
Fang Guan a,b,c,t, Xiaomin Zhang a,b, †, Yuefeng Song a,b,c, Yingjie Zhou a,b, Guoxiong Wang a,b,*, \\ Xinhe Bao ${ }^{\mathrm{a}, \mathrm{b}, \#}$ \\ a State Key Laboratory of Catalysis, Dalian Institute of Chemical Physics, Chinese Academy of Sciences, Dalian 116023, Liaoning, China \\ b Dalian National Laboratory for Clean Energy, Dalian Institute of Chemical Physics, Chinese Academy of Sciences, Dalian 116023, Liaoning, China \\ c University of Chinese Academy of Sciences, Beijing 100049, China
}

\section{A R T I C L E I N F O}

\section{Article history:}

Received 29 May 2018

Accepted 6 June 2018

Published 5 September 2018

\section{Keywords:}

$\mathrm{Gd}_{0.2} \mathrm{Ce}_{0.8} \mathrm{O}_{1.9}$ nanoparticles

$\mathrm{La}_{0.6} \mathrm{Sr}_{0.4} \mathrm{Co}_{0.2} \mathrm{Fe}_{0.8} \mathrm{O}_{3-\delta}$ anode

Oxygen evolution reaction

Three phase boundaries

Solid oxide electrolysis cell

\section{A B S T R A C T}

$\mathrm{La}_{0.6} \mathrm{Sr}_{0.4} \mathrm{Co}_{0.2} \mathrm{Fe}_{0.8} \mathrm{O}_{3-\delta}$ (LSCF) anodes were infiltrated by $\mathrm{Gd}_{0.2} \mathrm{Ce}_{0.8} \mathrm{O}_{1.9}$ (GDC) nanoparticles to improve the oxygen evolution reaction (OER) performance of solid oxide electrolysis cells (SOECs) in $\mathrm{CO}_{2}$ electroreduction. The effect of GDC loading was investigated, and $10 \mathrm{wt} \% \mathrm{GDC}$ nanoparticle infiltration of the LSCF (10GDC/LSCF) anode results in the highest OER performance. Electrochemical impedance spectra measurements indicate that the infiltration by GDC nanoparticles greatly decreases the polarization resistance of the SOECs with the 10GDC/LSCF anodes. The following distribution of relaxation time analysis suggests that four individual electrode processes are involved in the OER and that all of them are accelerated on the 10GDC/LSCF anode. Three phase boundaries, surface oxygen vacancies, and bulk oxygen mobility increased, based on scanning electron microscopy and temperature-programmed desorption of $\mathrm{O}_{2}$ characterizations, and contributed to the enhancement of the four electrode processes of the OER and electrochemical performance of SOECs.

(C) 2018, Dalian Institute of Chemical Physics, Chinese Academy of Sciences. Published by Elsevier B.V. All rights reserved.

\section{Introduction}

The massive emission of $\mathrm{CO}_{2}$ due to the heavy use of fossil fuels has posed serious challenges to the climate and environment during the past decades [1]. A solid oxide electrolysis cell (SOEC), which can electrolyze $\mathrm{CO}_{2}$ into $\mathrm{CO}$ with high efficiency, can utilize the electricity produced by intermittent renewable energy to alleviate $\mathrm{CO}_{2}$ emissions and fossil fuel consumption, and has therefore attracted extensive attention [2-4]. Compared with $\mathrm{CO}_{2}$ electroreduction in liquid electrolytes at room temperature [5-8], SOEC has a solid-state configuration, which potentially avoids corrosion and leakage problems. Furthermore, the high operating temperature of SOECs also presents great advantages in terms of kinetics and thermodynamics [2], thus achieving high current density and energy conversion efficiency for $\mathrm{CO}_{2}$ electroreduction and avoiding the use of ex-

\footnotetext{
* Corresponding author. E-mail: wanggx@dicp.ac.cn

\# Corresponding author. E-mail: xhbao@dicp.ac.cn

†These authors have contributed equally.

This work was supported by the National Key R\&D Program of China (2017YFA0700102), the National Natural Science Foundation of China (21703237, 21573222, 91545202), Dalian Institute of Chemical Physics (DICP DMT0201702), the Strategic Priority Research Program of the Chinese Academy of Sciences (XDB17020200) and CAS Youth Innovation Promotion (2015145).

DOI: 10.1016/S1872-2067(18)63118-3 | http://www.sciencedirect.com/science/journal/18722067 | Chin. J. Catal., Vol. 39, No. 9, September 2018
} 
pensive noble metals [9].

A typical SOEC is assembled using a porous cathode, compact $\mathrm{Y}_{2} \mathrm{O}_{3}$-stabilized $\mathrm{ZrO}_{2}$ (YSZ) electrolyte, and porous anode in the form of a "sandwich" [3]. For $\mathrm{CO}_{2}$ electroreduction in SOECs, the $\mathrm{CO}_{2}$ reactant gas diffuses to the three phase boundaries (TPBs) of the cathode and is reduced to $\mathrm{CO}$ and $\mathrm{O}^{2-}$ by accepting two electrons; the produced $\mathrm{CO}$ is released from the cathode surface, while $0^{2-}$ combines with an oxygen vacancy $\left(\mathrm{V}_{\mathrm{O} \text {, cathode }}^{\text {*. }}\right)$ to form lattice oxygen $\left(\mathrm{O}_{\mathrm{O} \text {, cathode }}^{\mathrm{x}}\right)$ (Reaction (1)). Then, $\mathrm{O}_{\mathrm{O} \text {, cathode }}^{\mathrm{x}}$ is conducted through the YSZ electrolyte via oxygen vacancies and evolves into $\mathrm{O}_{2}$ at the TPBs of the anode by losing electrons (Reaction (2)). Apparently, the oxygen evolution reaction (OER) occurring at the anode is a four-electron process, suggesting that anode polarization might dominate the polarization loss of SOEC during $\mathrm{CO}_{2}$ electroreduction [10]. Therefore, developing anode materials with high electrocatalytic activity for the OER is required to effectively improve the performance of SOECs in $\mathrm{CO}_{2}$ electroreduction.

$$
\begin{gathered}
\mathrm{CO}_{2}+2 \mathrm{e}^{-}+\mathrm{V}_{\mathrm{O} \text {, cathode }}^{\bullet \cdot} \rightarrow \mathrm{CO}+\mathrm{O}_{\mathrm{O} \text {, cathode }}^{\mathrm{X}} \\
2 \mathrm{O}_{\mathrm{O} \text {, anode }}^{\mathrm{X}} \rightarrow \mathrm{O}_{2}+4 \mathrm{e}^{-}+2 \mathrm{~V}_{\mathrm{O} \text {, anode }}^{\bullet}
\end{gathered}
$$

According to Reaction (2), an excellent anode material for the OER has good electronic conductivity, high electrocatalytic activity, as well as a large number of oxygen vacancies (which is related to ionic conductivity). ( $\mathrm{La}, \mathrm{Sr})(\mathrm{Co}, \mathrm{Fe}) \mathrm{O}_{3-\delta}$ (LSCF), which is commonly used in solid oxide fuel cells as an oxygen reduction reaction cathode material, has been investigated as a promising OER anode material for SOEC, owing to its mixed conductivity and superior electrocatalytic activity [11]. Unfortunately, the conventional LSCF anode suffers from limited electrocatalytic activity in $\mathrm{CO}_{2}$ electrolysis because the pure LSCF anode can only provide LSCF-gas two-phase boundaries (2 PBs) for the OER. It has been widely accepted that the electroreduction reactions at the LSCF-gas-doped ceria TPBs are much more facile than that at the LSCF-gas 2 PBs [12]. Thus, introducing doped ceria nanoparticles would be an effective strategy for improving the electrocatalytic activity of the LSCF anode, since these nanoparticles not only exhibit a much higher catalytic activity but also can create critical gas-doped ceria-LSCF TPBs for the OER.

In order to enhance the OER performance on a LSCF-based anode in $\mathrm{CO}_{2}$ electroreduction, the conventional LSCF anode was modified by using $\mathrm{Gd}_{0.2} \mathrm{Ce}_{0.8} \mathrm{O}_{1.9}$ (GDC) nanoparticles, and a YSZ electrolyte-supported SOEC with the corresponding LSCF-based anodes were fabricated in this work. Introducing GDC nanoparticles in the LSCF anode would not only create abundant active LSCF-GDC-gas TPBs for the OER but also lead to increased surface oxygen vacancies and enhanced bulk oxygen mobility of the anode. The improved performance of SOECs with respect to $\mathrm{CO}_{2}$ electroreduction is achieved by using GDC nanoparticles-modified LSCF anodes. Further, electrochemical impedance spectra (EIS) combined with the distribution of relaxation times (DRT) was employed to analyze the electrode reactions of $\mathrm{CO}_{2}$ electroreduction, and five individual electrode processes were identified. The enhancement mechanism of the $\mathrm{OER}$ as a result of GDC nanoparticle introduction was disclosed by discussing the distinct differences in the electrode processes between conventional LSCF and modified GDC/LSCF anodes.

\section{Experimental}

\subsection{Cell preparation}

YSZ electrolyte-supported SOECs were employed in this work. YSZ electrolyte pellets were fabricated by dry pressing 8 mol\% YSZ (Tosoh) powder at $42 \mathrm{MPa}$, followed by heat treatment at $1450{ }^{\circ} \mathrm{C}$ for $10 \mathrm{~h}$. The prepared electrolyte pellets were $20 \mathrm{~mm}$ in diameter and $0.5 \mathrm{~mm}$ in thickness.

$\mathrm{La}_{0.6} \mathrm{Sr}_{0.4} \mathrm{Co}_{0.2} \mathrm{Fe}_{0.8} \mathrm{O}_{3-\delta}$ (LSCF) powder was prepared by a modified Pechini-type method [13,14]. $\mathrm{La}\left(\mathrm{NO}_{3}\right)_{2} \cdot 6 \mathrm{H}_{2} \mathrm{O}$ (AR, Aladdin Industrial Corporation), $\mathrm{Sr}\left(\mathrm{NO}_{3}\right)_{2}$ (AR, Sinopharm Chemical Reagent), $\mathrm{Fe}\left(\mathrm{NO}_{3}\right)_{3} \cdot 9 \mathrm{H}_{2} \mathrm{O}$ (AR, Sinopharm Chemical Reagent), and $\mathrm{Co}\left(\mathrm{NO}_{3}\right)_{2} \cdot 6 \mathrm{H}_{2} \mathrm{O}$ (AR, Sinopharm Chemical Reagent) were dissolved in distilled water. Ammonium citrate (AR, Sinopharm Chemical Reagent) with a molar content 1.2 times that of metal ions was then added as a complexing agent and nitric acid was used to adjust the $\mathrm{pH}$ to around 1 . The solution was warmed to $80^{\circ} \mathrm{C}$ and excess water was evaporated under stirring to obtain a viscous gel. Then, the gel was continued to be heated at around $100{ }^{\circ} \mathrm{C}$ to induce self-propagating combustion and obtain the deep reddish-brown and loose powder. Finally, the powder was collected and calcined at $1000^{\circ} \mathrm{C}$ for 2 $\mathrm{h}$ to obtain the pure LSCF perovskite phase. Similarly, GDC powder was prepared by using the same methods as the LSCF powder.

LSCF $\mid$ GDC $\mid$ YSZ $\mid$ GDC|LSCF assembles were first fabricated. Briefly, GDC and LSCF slurries were prepared by dispersing GDC and LSCF powders, respectively, in a solution of $6 \mathrm{wt} \%$ ethyl cellulose (AR, Secoma) and $94 \mathrm{wt} \%$ terpinol (AR, Alfa Aesar). The GDC slurry was spin-coated on both sides of the YSZ electrolyte symmetrically and sintered at $1300^{\circ} \mathrm{C}$ for $2 \mathrm{~h}$ to form buffer layers with the purpose of avoiding undesired interactions between the LSCF electrode and YSZ electrolyte. The LSCF slurry was then printed on the GDC layers and treated at $1100{ }^{\circ} \mathrm{C}$ for $2 \mathrm{~h}$ to obtain the LSCF|GDC|YSZ|GDC|LSCF assembles, and the area of the LSCF layer is about $0.5 \mathrm{~cm}^{2}$. A $1.5 \mathrm{~mol}$ $\mathrm{L}^{-1} \mathrm{GDC}$ aqueous solution was prepared using $\mathrm{Ce}\left(\mathrm{NO}_{3}\right)_{3} \cdot 6 \mathrm{H}_{2} \mathrm{O}$ (AR, Sinopharm Chemical Reagent) and $\mathrm{Gd}\left(\mathrm{NO}_{3}\right)_{3} \cdot 6 \mathrm{H}_{2} \mathrm{O}$ (AR, Shanghai Chemical Reagent) as raw materials. In this work, LSCF layer on one side of the LSCF|GDC|YSZ|GDC|LSCF assembles was loaded with $5 \mathrm{wt} \%$ GDC nanoparticles that acted as the SOEC cathode, while the LSCF layeron the other side acted as the SOEC anode (LSCF anode). Different proportions of 3, 5, 10 , and $20 \mathrm{wt} \%$ of GDC nanoparticles were introduced to modify the LSCF anode by infiltrating appropriate amounts of the GDC solution and sintering at $800{ }^{\circ} \mathrm{C}$ for $2 \mathrm{~h}$; these modified anodes were denoted as 3GDC/LSCF, 5GDC/LSCF, 10GDC/LSCF, and 20GDC/LSCF anodes, respectively.

\subsection{Physicochemical characterization}

The phase compositions of the anodes were investigated by X-ray diffraction (XRD) analysis using a PANalytical Empyrean diffractometer equipped with a $\mathrm{Cu} K_{\alpha}$ radiation source $(\lambda=$ $1.5418 \AA$ A) operating at $40 \mathrm{~mA}$ and $40 \mathrm{kV}$. The microstructures of the anodes were observed with a FEI QUANTA 200F scan- 
ning electron microscope (SEM) operating at $20 \mathrm{kV}$ and a JEM-2100 transmission electron microscopy (TEM) at $200 \mathrm{kV}$. Temperature-programmed desorption of $\mathrm{O}_{2}\left(\mathrm{O}_{2}\right.$-TPD) was performed on an Auto Chem II 2920 instrument equipped with a mass spectrometer (OmniStar ${ }^{\mathrm{TM}}$ ). The anode samples (40-60 mesh) were first pretreated at $800{ }^{\circ} \mathrm{C}$ in pure $\mathrm{He}\left(50 \mathrm{~mL} \mathrm{~min}^{-1}\right)$ for $30 \mathrm{~min}$ and then cooled to room temperature in the same atmosphere. Subsequently, the samples were switched to $\mathrm{O}_{2}$ and treated for $30 \mathrm{~min}$ at room temperature, and then pure $\mathrm{He}$ was used to flush them with the purpose of purging the physically adsorbed oxygen and stabilizing the baseline. Finally, $\mathrm{O}_{2}$ was liberated by heating the samples from room temperature to $800{ }^{\circ} \mathrm{C}$ at a heating rate of $10^{\circ} \mathrm{C} \mathrm{min}^{-1}$ in pure He by monitoring the signal of $m / z=32$.

\subsection{Electrochemical measurements}

Electrochemical measurements of the SOECs were performed on a home-made device [10]. Before the test, Au slurry was printed on both the anode and cathode and fired at $500{ }^{\circ} \mathrm{C}$ for $1 \mathrm{~h}$ to serve as the current collector. A mixture of $95 \% \mathrm{CO}_{2}+$ $5 \% \mathrm{~N}_{2}$ flowed to the cathode at a rate of $50 \mathrm{~mL} \mathrm{~min}^{-1}\left(5 \% \mathrm{~N}_{2}\right.$ was used to calculate the Faradaic efficiency of $\mathrm{CO}$ as an internal standard gas), while the anode was exposed to static air. The products of $\mathrm{CO}_{2}$ electroreduction were detected by on line micro gas chromatography (Agilent 490) equipped with a Molsieve $5 \mathrm{~A}$ column and TCD detector. The $I-V$ curves, chronoamperometry curves, and EIS were measured on an electrochemical station (PGSTAT302N, Metrohm, Switzerland). The I-V curves were collected from 1.0 to $1.6 \mathrm{~V}$ at a scan rate of $5 \mathrm{mV}$ $\mathrm{s}^{-1}$. The EIS were obtained in the frequency range $1 \mathrm{MHz}$ to 0.05 $\mathrm{Hz}$ with a signal amplitude of $10 \mathrm{mV}$.

\section{Results and discussion}

\subsection{Physicochemical properties of anodes}

Fig. 1 displays the XRD patterns of the LSCF and modified GDC/LSCF anodes. The phase composition of LSCF perovskite can be obviously identified for all the anodes, according to the JCPDS data of PDF \#49-0284; such a structure ensures the

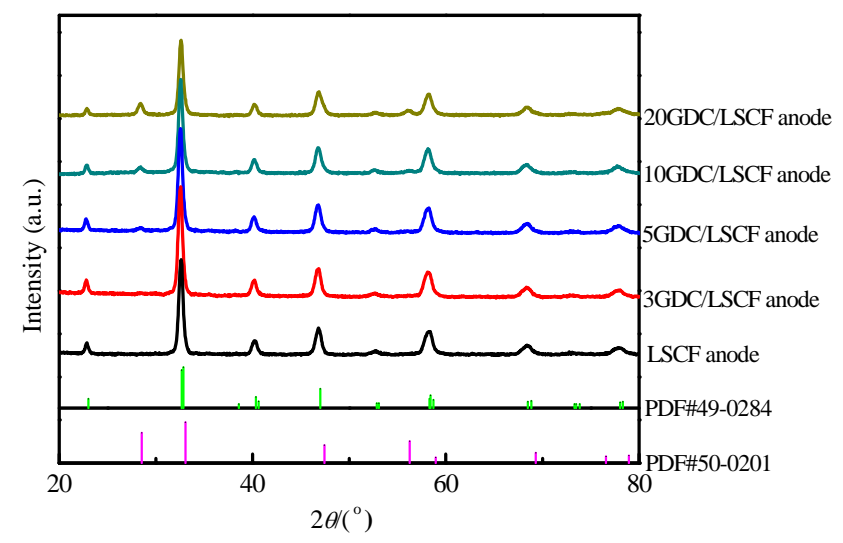

Fig. 1. XRD patterns of LSCF and GDC/LSCF anodes. electronic conductivity of the SOEC anode during the OER. Compared with the LSCF anode, new peaks of GDC fluorite emerged for the 5GDC/LSCF, 10GDC/LSCF, and 15GDC/LSCF anodes, according to the JCPDS data of PDF \#50-0201, since GDC nanoparticles were introduced on the LSCF surface. To be noted, no obvious diffraction peaks of GDC are detected for the 3GDC/LSCF anode because of its low GDC content. Moreover, with increasing GDC loading, the intensity of the GDC diffraction peaks gradually enhanced. Fig. 1 also shows that no impurity peaks or peak shifts are observed in the XRD patterns of the GDC/LSCF anodes, which is indicative of the good chemical compatibility between the GDC nanoparticles and LSCF anode.

In Fig. 2, the typical SEM images of the LSCF and GDC/LSCF anodes, as well as the TEM image of the infiltrated GDC nanoparticles, are illustrated. As shown in Fig. 2(a), LSCF particles with sizes of ca. 200-700 nm are closely connected to form a porous LSCF anode, which reveals continuous electron conduction paths, provides sites for the OER, and facilitates the diffusion of the oxygen molecules generated. After GDC infiltration, the GDC nanoparticles are dispersed on the LSCF anode (Fig. 2(b)-(e)). It can be clearly seen that the number of GDC nanoparticles on the LSCF anode gradually increase with GDC loading. For the 3GDC/LSCF anode (Fig. 2(b)), only a small number of GDC nanoparticles are sparsely dispersed on the LSCF anode surface due to its low GDC loading, which is consistent with the XRD results. With increasing GDC loading, the nanoparticles gradually form a nanonetwork on the LSCF anode surface (Fig. 2(c) and (d)), thus creating abundant active LSCF-GDC-gas TPBs for the OER. However, there appears to be coarsening of

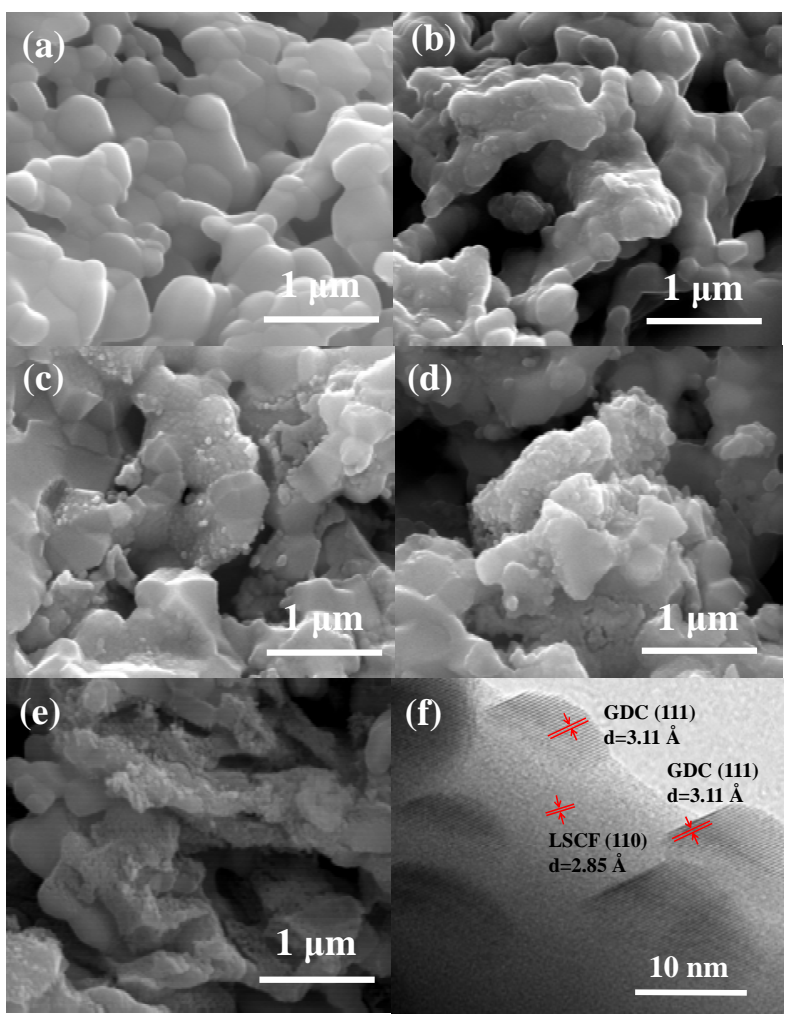

Fig. 2 Sectional SEM images of LSCF (a), 3GDC/LSCF (b), 5GDC/LSCF (c), 10GDC/LSCF (d), and 20GDC/LSCF (e) anodes, (f) HR-TEM image of the 10GDC/LSCF anode. 
the GDC nanoparticles when the GDC loading is further increased to $20 \mathrm{wt} \%$ (Fig. 2(e)), because high GDC loading tends to cause nanoparticle growth during the sintering process. This has a negative effect on the enlargement of TPBs, while the accumulated GDC nanoparticles might also retard $\mathrm{O}_{2}$ diffusion at the anode. Furthermore, we evaluate the size of the GDC nanoparticles via high resolution-TEM (HR-TEM) measurements. Owing to the low sintering temperature, GDC nanoparticles with sizes of ca. $10 \mathrm{~nm}$ are obtained in this work (Fig. 2(f)), which facilitates the formation of high TPBs.

The adsorption property of the anodes for $\mathrm{O}_{2}$ evolution is closely related to their performance in the OER. Therefore, $\mathrm{O}_{2}$-TPD of the LSCF anode was performed in this work. For comparison, the $\mathrm{O}_{2}$-TPD for a typical 10GDC/LSCF anode was also performed to investigate the influence of the introduction of GDC nanoparticles. As shown in Fig. 3, for both the LSCF and 10GDC/LSCF anodes, two $\mathrm{O}_{2}$ desorption peaks centered at temperatures of $295{ }^{\circ} \mathrm{C}$ ( $\alpha$-oxygen) and $760{ }^{\circ} \mathrm{C}$ ( $\beta$-oxygen) are observed in the low- and high-temperature ranges, respectively. The $\alpha$-oxygen originates from the liberation of the weakly chemisorbed oxygen species on the anode surface [15-18]. From the inset in Fig. 3, it can be seen that the 10GDC/LSCF anode exhibits a larger $\alpha$-oxygen desorption peak than the LSCF anode, which might be attributed to the increased specific surface area of the 10GDC/LSCF anode due to the introduction of the GDC nanoparticles. The $\beta$-oxygen peak observed at the higher temperature is ascribed to the desorption of bulk oxygen, accompanied by the partial reduction of higher valence Fe or Co ions [19]. Considering that the desorption of $\beta$-oxygen is realized through the exchange of bulk and surface oxygen vacancies $[20,21]$, the mobility of bulk oxygen in the anode could be reflected in the intensity of the desorption peak. Here, the 10GDC/LSCF anode presents a much larger $\beta$-oxygen desorption peak than the LSCF anode, indicating that the introduction of nanosized GDC particles results in increased surface oxygen vacancies and enhanced mobility of bulk oxygen. This is crucial for improving the OER performance of the LSCF anode, because abundant oxygen vacancies and enhanced bulk oxygen mobility

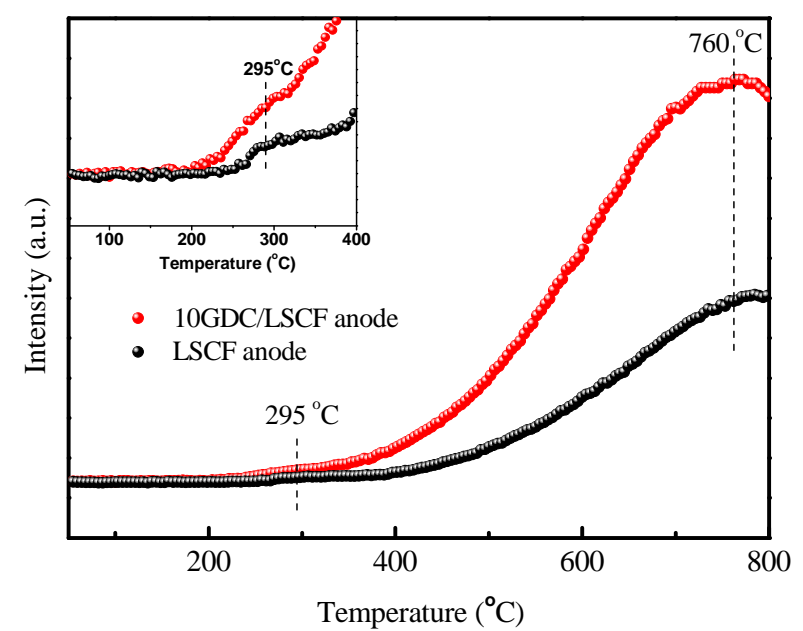

Fig. $3 \mathrm{O}_{2}$-TPD plots of LSCF and 10GDC/LSCF anodes (Inset: enlarged $\alpha$-oxygen desorption peaks). accelerate Reaction (2) at the anode. Thereby, the $\mathrm{O}_{2}$-TPD results suggest that OER would be greatly promoted by loading GDC nanoparticles onto the conventional LSCF anode.

\subsection{Electrochemical performance}

To validate the enhancement in performance due to the incorporation of GDC nanoparticles in the LSCF anode, the SOECs based on the LSCF and GDC/LSCF anodes were employed in $\mathrm{CO}_{2}$ electroreduction. In Fig. 4(a), the typical $I-V$ curves of the SOECs are illustrated. At $800{ }^{\circ} \mathrm{C}$, current density shows an increase with increasing voltage. As shown in Fig. 4(a), for the same voltage, current density appears a peak curve change with increasing loading of GDC nanoparticles, and maximum current density is achieved for the SOEC with the 10GDC/LSCF anode. This point is well illustrated by the chronoamperometry measurement at $800{ }^{\circ} \mathrm{C}$ and $1.6 \mathrm{~V}$. According to Fig. 4(b), current density of the SOEC with the LSCF anode is $0.420 \mathrm{~A} \mathrm{~cm}^{-2}$ at $800{ }^{\circ} \mathrm{C}$ and $1.6 \mathrm{~V}$, which would increase to $0.473 \mathrm{~A} \mathrm{~cm}^{-2}$ when introducing $3 \mathrm{wt} \%$ GDC nanoparticles in the LSCF anode. The maximum current density of $0.555 \mathrm{~A} \mathrm{~cm}^{-2}$ is obtained when increasing the GDC loading to $10 \mathrm{wt} \%$. With further increase in the GDC loading to $20 \mathrm{wt} \%$, a decline in the current density of the SOEC $\left(0.514 \mathrm{~A} \mathrm{~cm}^{-2}\right)$ is observed. In Fig. 4 (c), the current densities of the conventional LSCF anode and optimal $10 \mathrm{GDC} / \mathrm{LSCF}$ anode at $800{ }^{\circ} \mathrm{C}$ are compared for various electrolysis voltages. Stable current densities of $0.521,0.369,0.233$, and $0.114 \mathrm{~A} \mathrm{~cm}^{-2}$ are achieved at $1.6,1.4,1.2$, and $1.0 \mathrm{~V}$, respectively, for the SOEC with the 10GDC/LSCF anode, which are about 1.3, 1.34, 1.45, and 1.81 times those of the SOEC with the conventional LSCF anode, respectively. This suggests that the OER on the LSCF anode could be greatly enhanced by the introduction of GDC nanoparticles at the same electrolysis conditions. Since identical cathodes and electrolytes are employed in the SOECs, their improved electrochemical performance should be attributed to the enhanced OER on the modified LSCF anodes. This implies that CO production, as well as the corresponding Faradaic efficiency, can be used to evaluate the OER occurring at the anode. In Fig. 4(d) the CO productions and Faradaic efficiencies of the LSCF and GDC/LSCF anodes are compared. $\mathrm{CO}$ is the main product of $\mathrm{CO}_{2}$ electroreduction in this work, and Faradaic efficiency is higher than $90 \%$ for the SOECs for both the anodes. At $800{ }^{\circ} \mathrm{C}$, CO productions for the SOEC with the 10GDC/LSCF anode are 3.26, 2.40, 1.54, and 0.75 $\mathrm{mL} \mathrm{min}^{-1} \mathrm{~cm}^{-2}$ at $1.6,1.4,1.2$, and $1.0 \mathrm{~V}$, respectively, which are significantly higher than those of the SOEC with the conventional LSCF anode $\left(2.37,1.75,0.95\right.$, and $0.45 \mathrm{~mL} \mathrm{~min}^{-1} \mathrm{~cm}^{-2}$, respectively). This confirms that the GDC nanoparticle-modified LSCF anode can effectively promote $\mathrm{CO}_{2}$ electroreduction owing to its enhanced OER activity.

\subsection{EIS analysis}

EIS measurements for the SOECs were performed to investigate the electrode reactions involved in $\mathrm{CO}_{2}$ electroreduction. Fig. 5 displays the EIS of the SOECs with the LSCF and 10GDC/LSCF anodes for various electrolysis voltages and op- 

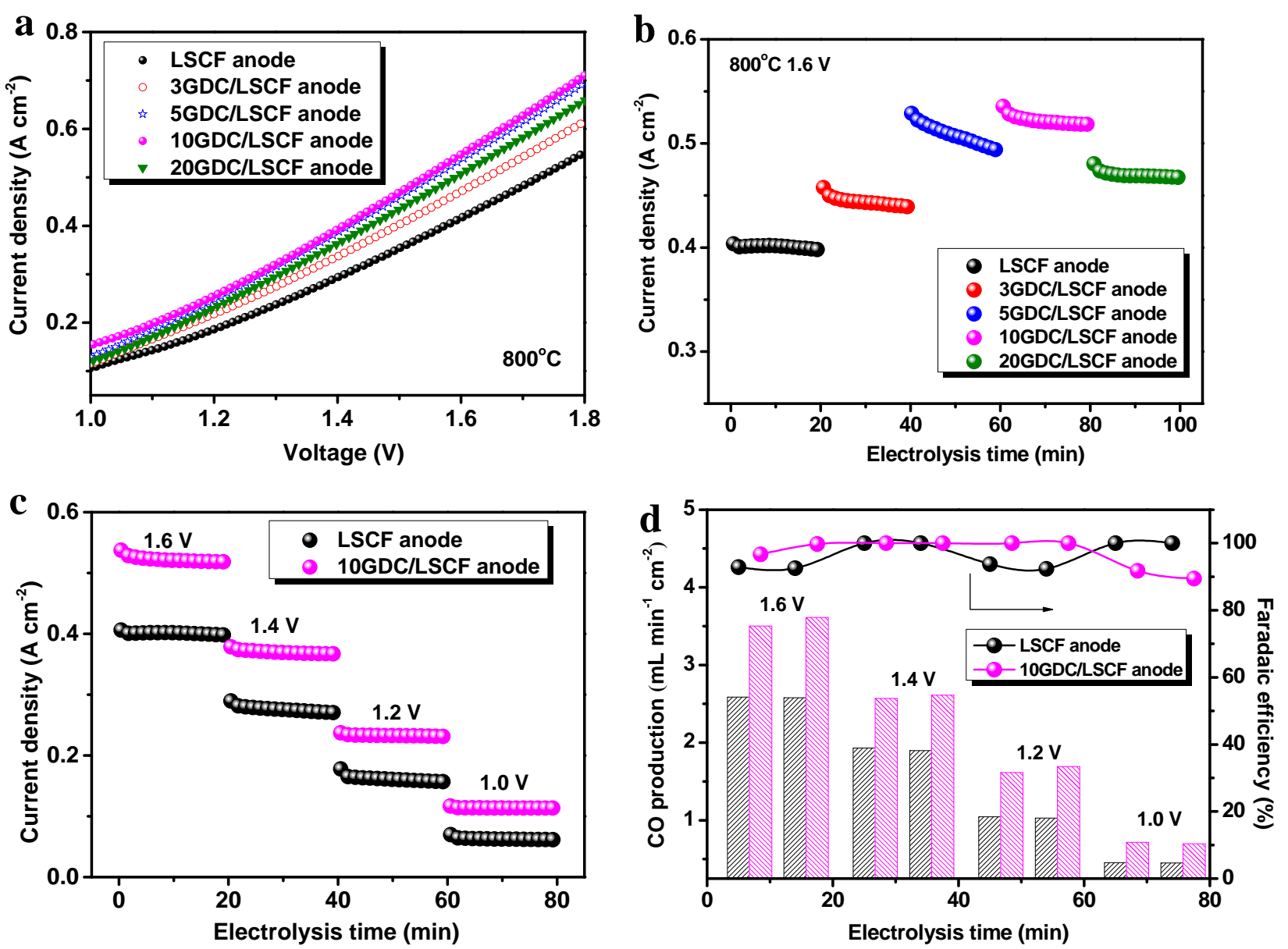

Fig. 4 Electrochemical performance of SOECs with LSCF and GDC/LSCF anodes. (a) $I$ - $V$ curves at $800{ }^{\circ} \mathrm{C}$; (b) Chronoamperometry curves at $800{ }^{\circ} \mathrm{C}$ and $1.6 \mathrm{~V}$; (c) Chronoamperometry curves of SOECs with LSCF and 10GDC/LSCF anodes at various voltages and $800{ }^{\circ} \mathrm{C}$; (d) CO productions and Faradaic efficiencies of the SOECs with the LSCF and 10GDC/LSCF anodes.

erating temperatures. In general, the high-frequency intercept of the EIS on the $\mathrm{x}$-axis $\left(\mathrm{Z}^{\prime}=0\right)$ represents the Ohmic resistance $\left(R_{\mathrm{ohm}}\right)$ of the operating SOEC, which is strongly dependent on the thickness of the YSZ electrolyte. Meanwhile, the distance between the highest and lowest frequency intercepts of the EIS on the $\mathrm{x}$-axis $\left(\mathrm{Z}^{\prime}=0\right)$ corresponds to the electrode polarization resistance $\left(R_{\mathrm{p}}\right)$, which mainly originates from the electrode reactions. Owing to the same YSZ electrolyte being employed, $R_{\text {ohm }}$ only shows a slight change before and after GDC nanoparticle introduction under the same conditions as those observed in Fig. 5(a) and (b). Notably, $R_{\mathrm{p}}$ presents distinct changes when different anodes are used for the SOECs. The higher the electrolysis voltage, the smaller is the $R_{\mathrm{p}}$ value. At $800{ }^{\circ} \mathrm{C}$, the SOEC with the 10GDC/LSCF anode displays $R_{\mathrm{p}}$ values of $0.225,0.288$, 0.389 , and $0.625 \Omega \mathrm{cm}^{2}$ at $1.6,1.4,1.2$, and $1.0 \mathrm{~V}$ respectively, which are only $54 \%, 53 \%, 51 \%$, and $55 \%$ of those of the SOEC with the conventional LSCF anode. The influence of operating temperature on $R_{\text {ohm }}$ and $R_{\mathrm{p}}$ are illustrated in Fig. 5(c) and (d). Apparently, a high temperature favors the reduction of $R_{\text {ohm }}$ and $R_{\mathrm{p}}$. To compare the differences between the LSCF and 10GDC/LSCF anodes, the $R_{\mathrm{ohm}}$ and $R_{\mathrm{p}}$ values are listed in Table 1. SOECs with different anodes reveal similar $R_{\text {ohm }}$ at the same operating temperature. However, compared with the conven- tional LSCF anode, the 10GDC/LSCF anode enables the SOEC to achieve a much lower $R_{\mathrm{p}}$. The EIS results suggest that the $R_{\mathrm{p}}$ of the SOEC is greatly reduced through the introduction of GDC nanoparticles in the LSCF anode owing to the enhanced OER on the GDC/LSCF anode.

EIS can be used to identify the individual electrode processes dominating SOEC performance by distinguishing the characteristic relaxation frequency difference of each process $[22,23]$. However, owing to the low frequency resolution of EIS, two neighboring electrode processes cannot be discriminated until they have at least two or three orders of magnitude difference in their characteristic relaxation frequency. As illustrated in Fig. 5, only two separate arcs are clearly observed, implying that significantly more electrode processes overlapped in these two individual EIS arcs that cannot be distinguished. In order to distinguish the overlapped individual electrode processes, the DRT with a high frequency resolution is applied to the deconvolution of EIS data in this work [24-26]. The DRT calculations were performed using the Ftikreg software package $[24,26]$. Fig. 6 exhibits the DRT results of the SOECs under different operating conditions based on the EIS data presented in Fig. 5. The peaks in the DRT plots represent the individual electrode processes overlapped in the EIS, and 

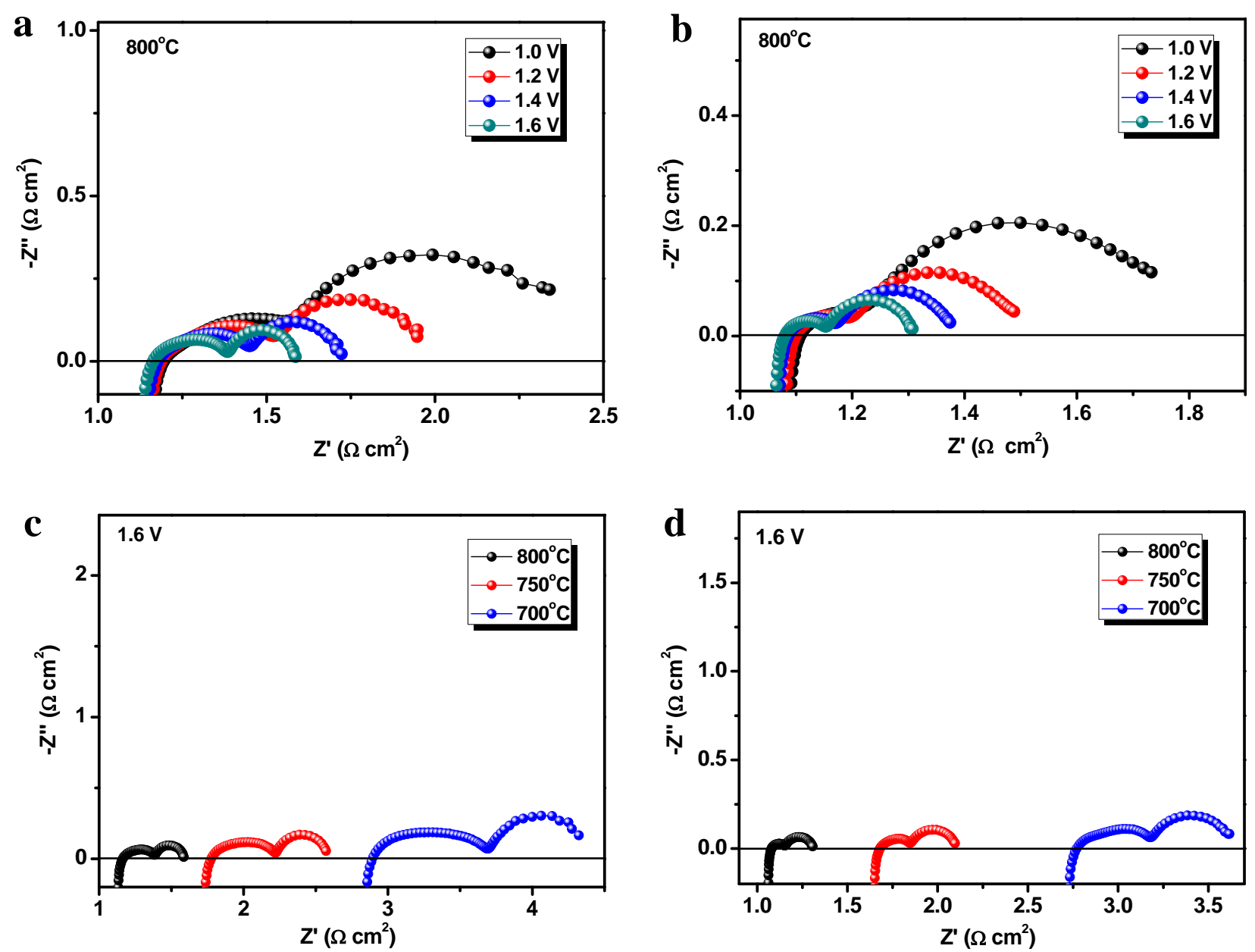

Fig. 5 EIS of SOECs with the LSCF anode (a) and 10GDC/LSCF anode (b) at $800^{\circ} \mathrm{C}$ for various electrolysis voltages; EIS of SOECs with the LSCF anode (c) and 10GDC/LSCF anode (d) at $1.6 \mathrm{~V}$ for various operating temperatures.

the peak area reflects the corresponding polarization resistance of each process. Five peaks marked P1 to P5 from the high to low frequency range are clearly observed in the DRT plots, suggesting that five individual electrode processes are involved based on the EIS. In Fig. 6(a) and (b), the five individual electrode processes are observed in similar frequency ranges and reveal the same trends with increasing operating temperature, indicating that the SOECs with the LSCF and 10GDC/LSCF anodes have the same individual electrode processes occurring in $\mathrm{CO}_{2}$ electroreduction. Furthermore, using the 10GDC/LSCF anode can remarkably reduce the peak areas associated with all the electrode processes, except that of $\mathrm{P} 4$ (Fig. 6(c)). This suggests that the introduction of GDC nanoparticles in the LSCF anode can decrease the polarization resistances of the related electrode processes, rather than

\section{Table 1}

$R_{\mathrm{p}}$ values of SOECs with the LSCF and 10GDC/LSCF anodes at $1.6 \mathrm{~V}$ for various operating temperatures.

\begin{tabular}{lccccc}
\hline $\begin{array}{l}\text { Tempera- } \\
\text { ture }\left({ }^{\circ} \mathrm{C}\right)\end{array}$ & \multicolumn{2}{c}{ SOEC with LSCF anode } & & \multicolumn{2}{c}{ SOEC with 10GDC/LSCF anode } \\
\cline { 2 - 3 } & $R_{\text {ohm }}\left(\Omega \mathrm{cm}^{2}\right)$ & $R_{\mathrm{p}}\left(\Omega \mathrm{cm}^{2}\right)$ & & $R_{\text {ohm }}\left(\Omega \mathrm{cm}^{2}\right)$ & $R_{\mathrm{p}}\left(\Omega \mathrm{cm}^{2}\right)$ \\
\hline 800 & 1.167 & 0.419 & & 1.080 & 0.227 \\
750 & 1.814 & 0.757 & & 1.681 & 0.416 \\
700 & 2.998 & 1.324 & & 2.770 & 0.847 \\
\hline
\end{tabular}

changing the mechanism of the electrode reactions occurring in SOECs. To be noted, since the same cathode is employed, the P4 process is probably ascribed to the $\mathrm{CO}_{2}$ electroreduction reaction at the cathode, whereas the P1-P3 and P5 processes must be OER-related anode processes. As displayed in Fig. 6(d), the P1 and P2 processes are slightly affected by the electrolysis voltage, though the P3-P5 processes strongly depend on this voltage. This suggests that the P3-P5 processes are charge transfer related processes.

Combining the above results with the literature [27-30], we assign $\mathrm{P} 1, \mathrm{P} 3, \mathrm{P} 2$, and $\mathrm{P} 5$ to $\mathrm{O}^{2-}$ transfer in the anode, $\mathrm{O}^{2-}$ losing an electron to form the $\mathrm{O}^{-}$intermediate species, surface diffusion of charged $\mathrm{O}^{-}$to $2 \mathrm{PBs} / \mathrm{TPBs}$, and $\mathrm{O}^{-}$releasing another electron to produce $\mathrm{O}_{2}$, respectively. The enhancement mechanism of the GDC/LSCF anode on the OER can be disclosed by analyzing the effect of the introduction of GDC nanoparticles on the electrode processes. In this work, introducing ionically conductive GDC nanoparticles in the LSCF anode significantly increases the ionic conductivity of the SOEC anode, enhancing the $\mathrm{O}^{2-}$ transfer process and reducing the corresponding polarization resistance of P1. Additionally, the existence of GDC nanoparticles also results in an increase in TPBs in the anode, shortening the diffusion path of the $\mathrm{O}^{-}$species and simultane- 

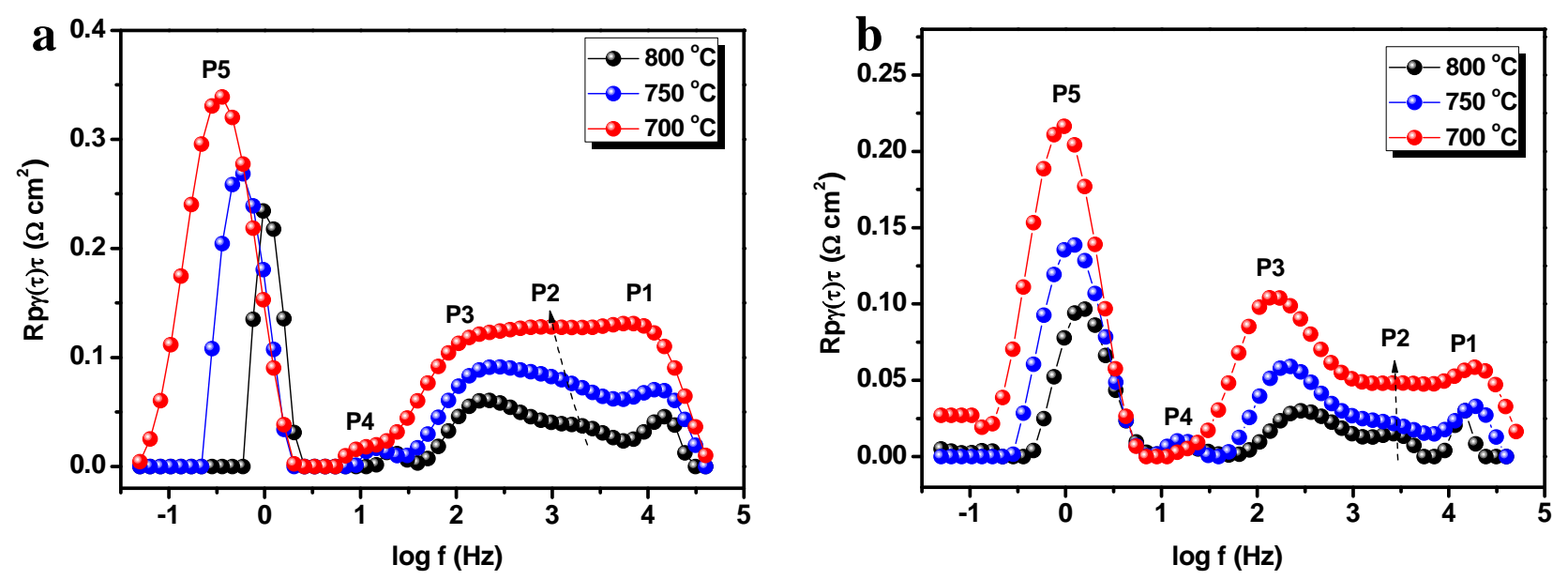

C
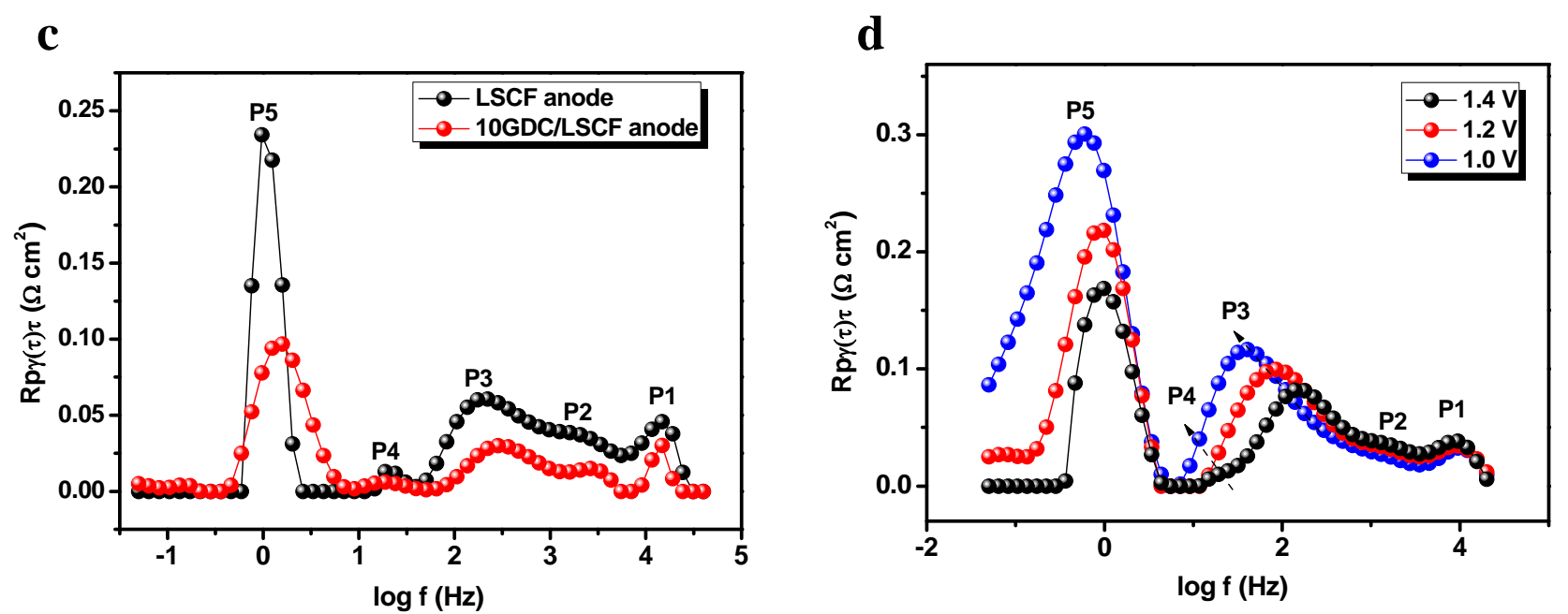

Fig. 6 DRT plots of SOECs with the LSCF anode (a) and 10GDC/LSCF anode (b) at $1.6 \mathrm{~V}$ for various operating temperatures; (c) DRT plots of SOECs with the LSCF and 10GDC/LSCF anodes at $800^{\circ} \mathrm{C}$ and $1.6 \mathrm{~V}$; (d) DRT plots of SOEC with the LSCF anode at $800{ }^{\circ} \mathrm{C}$ for various electrolysis voltages.

ously enhancing the mobility of bulk oxygen, which when taken together, contribute to obviously accelerated charge transfer (P3 and P5) processes, as well as the surface diffusion process (P2).

\section{Conclusions}

GDC nanoparticles of sizes ca. $10 \mathrm{~nm}$ are deposited on the surface of a porous LSCF anode by a one-step solution infiltration process that results in significant OER performance enhancement in SOECs. EIS and DRT analysis indicate that the OER at the SOEC anode occurs through four individual electrode processes: $\mathrm{O}^{2-}$ transfer at the anode, $\mathrm{O}^{2-}$ loses an electron to form the $\mathrm{O}^{-}$intermediate species, surface diffusion of the charged $\mathrm{O}^{-}$to the $2 \mathrm{PBs}$ or TPBs, and $\mathrm{O}^{-}$loses the remaining electron to generate $\mathrm{O}_{2}$. These four individual electrode processes are all enhanced at the 10GDC/LSCF anode because the introduction of GDC nanoparticles significantly increases the TPBs, surface oxygen vacancies, and bulk oxygen mobility, according to SEM and $\mathrm{O}_{2}$-TPD results, which contributed to the performance improvement of the SOECs with the GDC/LSCF anode.

\section{References}

[1] G. P. Peters, C. Le Quéré, R. M. Andrew, J. G. Canadell, P. Friedlingstein, T. Ilyina, R. B. Jackson, F. Joos, J. I. Korsbakken, G. A. McKinley, S. Sitch, P. Tans, Nature Clim. Change, 2017, 7, 848-850.

[2] Y. Zheng, J. Wang, B. Yu, W. Zhang, J. Chen, J. Qiao, J. Zhang, Chem. Soc. Rev., 2017, 46, 1427-1463.

[3] X. Zhang, Y. Song, G. Wang, X. Bao, J. Energy Chem., 2017, 26, 839-853.

[4] Q. Fu, C. Mabilat, M. Zahid, A. Brisse, L. Gautier, Energy Environ. Sci., 2010, 3, 1382-1397.

[5] J. Wu, X. D. Zhou, Chin. J. Catal., 2016, 37, 999-1015.

[6] J. Kong, W. Cheng, Chin. J. Catal, 2017, 38, 951-969.

[7] Y. Huang, M. Zhang, P. Liu, F. Cheng, L. Wang, Chin. J. Catal., 2016, $37,1249-1256$.

[8] X. Leng, K. H. Wu, B. J. Su, L. Y. Jang, I. R. Gentle, D. W. Wang, Chin. J. Catal., 2017, 38, 1021-1027.

[9] L. Cao, S. Jiang, G. Zhang, X. Tang, X. Qin, Z. Shao, B. Yi, Chin. J. Catal, 2017, 38, 1196-1206.

[10] Y. Song, X. Zhang, Y. Zhou, Q. Jiang, F. Guan, H. Lv, G. Wang, X. Bao, Energy Storage Mater., 2018, 13, 207-214. 


\title{
Graphical Abstract
}

Chin. J. Catal., 2018, 39: 1484-1492 doi: 10.1016/S1872-2067(18)63118-3

\section{Effect of $\mathrm{Gd}_{0.2} \mathrm{Ce}_{0.8} \mathrm{O}_{1.9}$ nanoparticles on the oxygen evolution reaction of $\mathrm{La}_{0.6} \mathrm{Sr}_{0.4} \mathrm{Co}_{0.2} \mathrm{Fe}_{0.8} \mathrm{O}_{3-\delta}$ anode in solid oxide electrolysis cell \\ Fang Guan, Xiaomin Zhang, Yuefeng Song, Yingjie Zhou, Guoxiong Wang *, Xinhe Bao * \\ Dalian Institute of Chemical Physics, Chinese Academy of Sciences; University of Chinese Academy of Sciences}

$\mathrm{Ce}_{0.8} \mathrm{Gd}_{0.2} \mathrm{O}_{1.9}$ nanoparticles infiltrated the $\mathrm{La}_{0.6} \mathrm{Sr}_{0.4} \mathrm{Co}_{0.2} \mathrm{Fe}_{0.8} \mathrm{O}_{3-\delta}$ anode and significantly enhanced the electrochemical performance of the oxygen evolution reaction in a solid oxide electrolysis cell for $\mathrm{CO}_{2}$ electroreduction.
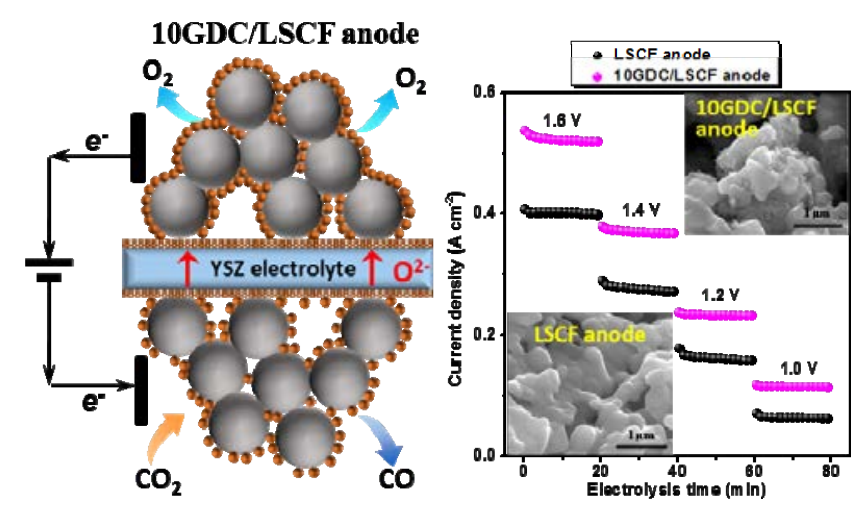

[11] O. A. Marina, L. R. Pederson, M. C. Williams, G. W. Coffey, K. D. Meinhardt, C. D. Nguyen, E. C. Thomsen, J. Electrochem. Soc., 2007, 154, B452-B459.

[12] B. Hu, Y. Wang, C. Xia, J. Power Sources, 2014, 269, 180-188.

[13] Q. Xu, D. P. Huang, W. Chen, J. H. Lee, H. Wang, R. Z. Yuan, Scripta Mater., 2004, 50, 165-170.

[14] W. Liu, Z. Zhao, B. Tu, D. Cui, D. Ou, M. Cheng, Chin. J. Catal,, 2015, $36,502-508$.

[15] X. Zhang, Y. Song, F. Guan, Y. Zhou, H. Lv, G. Wang, X. Bao, J. Catal., 2018, 359, 8-16.

[16] E. Bucher, W. Sitte, G. B. Caraman, V. A. Cherepanov, T. V. Aksenova, M. V. Ananyev, Solid State Ionics, 2006, 177, 3109-3115.

[17] P. Zeng, R. Ran, Z. Chen, H. Gu, Z. Shao, J. C. Diniz Dacosta, S. Liu, J. Membr. Sci., 2007, 302, 171-179.

[18] A. Mineshige, J. Izutsu, M. Nakamura, K. Nigaki, J. Abe, M. Kobune, S. Fujii, T. Yazawa, Solid State Ionics, 2005, 176, 1145-1149.

[19] R. Dinamarca, X. Garcia, R. Jimenez, J. L. G. Fierro, G. Pecchi, Mater. Res. Bull., 2016, 81, 134-141.

[20] K. Wang, L. Qian, L. Zhang, H. Liu, Z. Yan, Catal. Today, 2010, 158, 423-426.
[21] B. Levasseur, S. Kaliaguine, J. Solid State Chem., 2008, 181, 2953-2963.

[22] Y. Tao, S. D. Ebbesen, M. B. Mogensen, J. Electrochem. Soc., 2014, 161, F337-F343.

[23] Y. Tao, S. D. Ebbesen, M. B. Mogensen, J. Power Sources, 2016, 328, $452-462$.

[24] B. Liu, H. Muroyama, T. Matsui, K. Tomida, T. Kabata, K. Eguchi, J. Electrochem. Soc., 2010, 157, B1858-B1864.

[25] A. Leonide, B. Rüger, A. Weber, W. A. Meulenberg, E. Ivers-Tiffée, J. Electrochem. Soc., 2010, 157, B234-B239.

[26] X. Zhang, W. Wu, Z. Zhao, B. Tu, D. Ou, D. Cui, M. Cheng, Catal. Sci. Technol., 2016, 6, 4945-4952.

[27] X. J. Chen, K. A. Khor, S. H. Chan, J. Power Sources, 2003, 123, $17-25$.

[28] J. D. Kim, G. D. Kim, J. W. Moon, Y. Park, W. H. Lee, K. Kobayashi, M. Nagai, C. E. Kim, Solid State Ionics, 2001, 143, 379-389.

[29] K. Asano, D. Klotz, J. Hayd, J. Szasz, E. Ivers-Tiffee, J. Electrochem. Soc., 2014, 161, F940-F943.

[30] J. Yan, Z. Zhao, L. Shang, D. Ou, M. Cheng, J. Power Sources, 2016, $319,124-130$.

\section{$\mathrm{Gd}_{0.2} \mathrm{Ce}_{0.8} \mathrm{O}_{1.9}$ 纳米颗粒对固体氧化物电解池 $\mathrm{La}_{0.6} \mathrm{Sr}_{0.4} \mathrm{Co}_{0.2} \mathrm{Fe}_{0.8} \mathrm{O}_{3-\delta}$ 阳极 析氧反应的影响}

\author{
关 放 ${ }^{\mathrm{a}, \mathrm{b}, \mathrm{c}, \dagger}$, 张小敏 ${ }^{\mathrm{a}, \mathrm{b}, \dagger}$, 宋月锋 ${ }^{\mathrm{a}, \mathrm{b}, \mathrm{c}}$, 周莹杰 ${ }^{\mathrm{a}, \mathrm{b}}$, 汪国雄 ${ }^{\mathrm{a}, \mathrm{b},{ }^{*}}$, 包信和 ${ }^{\mathrm{a}, \mathrm{b}, \#}$ \\ ${ }^{\mathrm{a}}$ 中国科学院大连化学物理研究所, 催化基础国家重点实验室, 辽宁大连116023 \\ b 中国科学院大连化学物理研究所, 洁净能源国家实验室(筹), 辽宁大连 116023 \\ c中国科学院大学, 北京100049
}

摘要: 化石燃料的使用排放了大量 $\mathrm{CO}_{2}$, 对气候和环境造成了日益严重的危害. 固体氧化物电解池(SOEC)能够利用可再生 能源产生的电能将 $\mathrm{CO}_{2}$ 高效转化成 $\mathrm{CO}$, 降低 $\mathrm{CO}_{2}$ 排放的同时, 又能减少化石燃料的使用, 近年来受到研究者的广泛关注. 相 比于低温液相 $\mathrm{CO}_{2}$ 电还原, SOEC高的运行温度保证了其较高的反应速率, 即较高的电流密度. 典型的SOEC单电池由多孔 阴极、致密电解质和多孔阳极以三明治的方式组装而成. $\mathrm{CO}_{2}$ 分子在阴极得到两个电子解离成 $\mathrm{CO}$ 和一个 $\mathrm{O}^{2-}$; 生成的 $\mathrm{O}^{2-}$ 通 过致密电解质传导至阳极, 在阳极失去四个电子发生析氧反应 ( OER) 生成一个 $\mathrm{O}_{2}$. 相比于两电子的阴极反应, 阳极四电 子的析氧反应更难进行, 可能是整个电极过程的速控步, 因此开发高性能的阳极材料有望显著提高 $\mathrm{SOEC}^{\text {的 }} \mathrm{CO}_{2}$ 电还原性 能.

$\mathrm{La}_{0.6} \mathrm{Sr}_{0.4} \mathrm{Co}_{0.2} \mathrm{Fe}_{0.8} \mathrm{O}_{3-\delta}$ (LSCF) 因具有较高的混合离子-电子导电性而被用作SOEC阳极材料, 但受LSCF-气体两相界面 
的限制, 其OER性能较低. 研究表明, LSCF-掺杂的CeO $2_{2}$-气体所构成的三相界面相比于LSCF-气体两相界面具有更高的电 化学反应活性, 即 OER反应更易在三相界面进行. 因此, 本文将 $\mathrm{Gd}_{0.2} \mathrm{Ce}_{0.8} \mathrm{O}_{1.9}(\mathrm{GDC})$ 纳米颗粒浸渍到SOEC LSCF阳极来提 高其OER活性, 考察了纳米颗粒浸渍量 $(3,5,10$ 和20 wt\%)对SOEC电化学性能的影响. 结果表明, SOEC的电化学性能随浸 渍量的增加而逐渐升高, 当GDC纳米颗粒浸渍量为 $10 \mathrm{wt} \%$ 时 (10GDC/LSCF), SOEC的电化学性能达到最高, 在 $800{ }^{\circ} \mathrm{C}$ 和 1.6 $\mathrm{V}$ 的电流密度为 $0.555 \mathrm{~A} \mathrm{~cm}^{-2}$, 是LSCF阳极SOEC性能的 1.32 倍. 继续增加浸渍量到 $20 \mathrm{wt} \%$, 电化学性能反而开始下降. 电 化学阻抗谱测试结果表明, GDC纳米颗粒的加入减小了SOEC的极化电阻. 对应的弛豫时间分布函数解析结果表明 10GDC/LSCF阳极上的OER 由四个基元反应构成. 电镜和 $\mathrm{O}_{2}$-程序升温脱附结果表明, GDC纳米颗粒的加入显著增加了 $10 \mathrm{GDC} / \mathrm{LSCF}$ 阳极三相界面和表面氧空位的数量以及体相氧的流动性, 从而促进了 OER四个基元反应的反应速率, 降低了 这几个过程的极化电阻, 因而降低了 OER反应的极化电阻, 提高了SOEC电还原 $\mathrm{CO}_{2}$ 的电化学性能.

关键词: $\mathrm{Gd}_{0.2} \mathrm{Ce}_{0.8} \mathrm{O}_{1.9}$ 纳米颗粒; $\mathrm{La}_{0.6} \mathrm{Sr}_{0.4} \mathrm{Co}_{0.2} \mathrm{Fe}_{0.8} \mathrm{O}_{3-8}$ 阳极; 析氧反应; 三相界面; 固体氧化物电解池

收稿日期: 2018-05-29. 接受日期: 2018-06-06. 出版日期: 2018-09-05.

*通讯联系人. 电子信箱: wanggx@dicp.ac.cn

\#通讯联系人. 电子信箱: xhbao@dicp.ac.cn

†共同第一作者.

基金来源: 国家重点研发计划(2017YFA0700102); 国家自然科学基金(21703237, 21573222, 91545202); 大连化学物理研究所 DMTO项目(DICP DMTO201702); 中国科学院先导专项(XDB17020200); 中国科学院青年创新促进会(2015145).

本文的电子版全文由Elsevier出版社在ScienceDirect上出版(http://www.sciencedirect.com/science/journal/18722067). 